Валерија Стефановић

Народна библиотека

„Доситеј Обрадовић”,

Нови Пазар

valerijanp@yahoo.com
Стручни рад

UDK 271.222(497.11)-523.6-282"17/18"

017:271.222(497.11)-523.6"17/18"

https://doi.org/10.18485/bibliotekar.2019.61.1.9

\title{
СТАРА ШТАМПАНА КЊИГА МАНАСТИРА СОПОЋАНИ У НОВОМ ПАЗАРУ
}

Сажетак: Истраживање старе штампане књиге у Новом Пазару има посебан и вишеструки значај и представља важан део културног наслеђа овог народа. Радом су обухваћене књиге које се чувају у библиотеци Манастира Сопоћани штампане у периоду од 1745. до 1894. године. Предмет наше анализе јесу следеће књиге: Псалиичр, издање из 1745. године, потом Молииевослов из 1771. и Ирмолоіија 1778 , Службе йосебним светима из 1785, Месещослов за щелу іолину, 1810, Служабник из

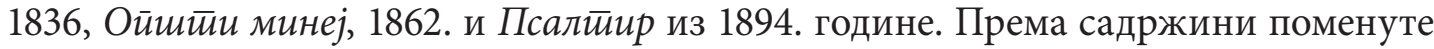
књиге су богослужбене и припадају категорији старе штампане књиге. Овим радом покушаћемо да их представимо јавности и на тај начин пружимо нове могућности у истраживању културног наслеђа. Истраживање ове грађе веома је значајно, те се надамо да ћемо њиме пробудити интересовање шире јавности на овом простору.

Кључне речи: стара штампана књига, богослужбене књиге, Манастир Сопоћани, Нови Пазар.

Када је реч о историјском развоју новопазарског краја, неспорна чињеница јесте да он представља један од најзанимљивијих региона Србије. Овај крај има посебан значај јер је био центар српске средњовековне државе Рашке. Творац те моћне државе је Стефан Немања, чија традиција владања је била дуга и веома успешна. Ово је крај где су рођени, расли и стварали први српски биографи (Растко Немањић - Свети Сава, Стефан Првовенчани) $)^{1}$.

1 Ејуп Мушовић, „Новопазарско-пријепољски крај у турској административној подели”, у Симйозијум Сеоски gани Сретеена Вукосвављевића IV, уредник Петар Влаховић (Пријепоље: Заједница основног образовања, 1976), 165. 
Стециште писмености, током свог постојања, био је Манастир Сопоћани јер је књига била неопходна за развој манастирског духовног живота. Манастир Сопоћани, задужбина краља Уроша I, изграђен у другој половини XIII века, између 1263. и 1268. године у области Раса - средишту српске средњовековне државе ${ }^{2}$. Краљ Урош I господарио је земљом од 1243. до 1276. године и био је један од најзначајнијих владара 13 века. ${ }^{3}$ Мудар, способан и образован, учврстио је границе државе и економски је ојачао. Политичке прилике и привредни успон створили су услове за развој културе, уметничког стваралаштва и градитељства, што је омогућило да, иако се пратила уметност Византије, Србија ствара сопствени стил и традицију ${ }^{4}$. На судбину манастира утицала су историјска дешавања. Током периода османлијске владавине Манастир Сопоћани је страдао $(1389,1587,1724)$, али је успео да одоли зубу времена и данас изазива дивљење савременика како својом величином и сјајем, тако и чињеницом да његово постојање говори о богатом културном животу Срба у средњем веку.

Услед огромног страдања Манастира Сопоћани, који је трпео разна поробљавања и разарања, писменост је опстајала у тихом манастирском животу. Први споменици писани руком налазе се на фрескама и датирају од оснивања манастира у 12. и 13. веку, а сачувани су до данас. Овде је настала једна од најзначајнијих рукописних књига српске писмености, $B y$ каново јеванђелье 5 , исписано око 1202. године у Расу, а које се чува у Санкт Петербургу. Налази се у Руској националној библиотеци од 1881. године, као део збирке епископа Порфирија Успенског.

На овим просторима књига је делила судбину српског народа. Трагајући за пореклом старе штампане књиге не можемо а да се не осврнемо и на значајне историјске догађаје. Један од њих јесте и велика прекретница у судбини српског народа, а то је Велика сеоба Срба у 17. веку под патријархом Арсенијем III Чарнојевићем. У том периоду изгубљен је и расут велики број рукописних и штампаних књига. Околности у којима је живео српски народ биле су тешке, пуне неизвесности, без наде да ће се створити услови

Светислав Мандић, Сойоћани (Београд: Туристичка штампа, 1965).

Hivzo Gološ, Ahmed Bihorac i Mirsada Gološ, Kralj Stefan Uroš Prvi Nemanjić (1243-1276) (Novi Pazar: Narodna biblioteka „Dositej Obradović”, 2018).

4 Оливера Кандић и Десанка Милошевић, Манасӣир Сойоћани (Београд: Републички завод за заштиту споменика културе, 1994), [5].

5 Налази се у Руској националној библиотеци од 1881. године, као део збирке епископа Порфирија Успенског, а састоји се од 190 листова величине 252 x 200 mm. Прво фототипско издање приређено је 1967. године захваљујући Јосипу Врани. 
за раст културе и литературе. Страх који је постојао код црквених великодостојника да не дође до покатоличавања Срба натерао их је да ослонац потраже у Русији и руској Цркви.

Као посебна целина у Манастиру Сопоћани налази се збирка старих богослужбених књиге, значајних по својим вредностима. Ово богато културно наслеђе, нажалост, пало је у заборав. Приликом нашег истраживања књиге смо затекли у манастирском ормару, а сами монаси нису били свесни њихове културне вредности, па је ово истраживање изазвало интересовање манастирског братства. Уз несебичну подршку оца Никодима, стручну помоћ оца Зосима и уз благослов игумана Теоктиста ${ }^{6}$, покушаћемо да представимо део старе штампане књиге која се налази у манастирској збирци.

Проучавајући порекло старе штампане књиге, анализирајући записе, имена и презимена, печате, рукописне белешке, само је делимично утврђено коме су припадале. Сачуваних писаних трагова, писама или неких докумената који би посведочили о начину на који су пристигле књиге у манастир, нажалост, нема.

У Манастиру Сопоћани налази се збирка од осам богослужбених књига, и у овом раду дајемо основне податке за њихову идентификацију. Најстарија књига у фонду јесте Псалиичр, настао у оквиру манастирске заједнице Илинско-Черњиговског у Русији, 1745; Молийвослов, штампан у царском Бечу, 1771; Ирмолоіија, у Москви, 1778; Службе йосебним свеииима, у Кијево-печерској лаври у Русији, 1785; Месецослов за иелу іобину, у Москви, 1810; Служабник, у Београду, 1836; Ойшӣи Минеј, у Москви, 1862. и Псаличир, у Москви, 1894. године.

ПСАЛТИР - Москва, 1745. - 273 стр; 17 cm. Формат књиге је 17 х $22 \mathrm{~cm}$. Најстарија књига у фонду манастирске библиотеке - Псалитир, шампана је 1745. године у штампарији Манастира Свете Тројице која је дејствовала у оквиру манастирске заједнице Илинско-Черњиговског у Русији.

Књига има кожни повез са металним копчама и са утиснутим орнаментом који симболизује Распеће Исусово, чиме се истиче духовни карактер књиге. Корични листови су делимично оштећени. Предња корица је очувана, али недостаје последњи корични лист. Псалтир није потпун, недостаје неколико листова на различитим местима, а последња нумерисана

6 На чему им и овом приликом, још једном, срдачно захваљујемо. 
страна јесте 273. Текст је на рускословенском језику, читљив и штампан једностубачно.

Уводна страна је илустрована и садржи графику на чијем врху се налази голуб, који симболизује Духа Светог којим су надахнути псалмопевци. На доњој страни графике налазе се три младића (Ананије, Азарије и Мисаил) бачени у огњену пећ од стране цара Навухудоносора, који су дејством Божје благодати остали неповређени, зато што су веровали у свога Бога којег је проповедао Мојсије. На левој и десној страни налазе се псалмопевци (било их је осам).

Запис на илустрованој страни гласи:

У славу свете једносушитне животиворне и неразделиве Тројице Оияа и

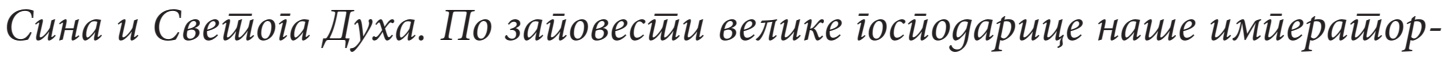

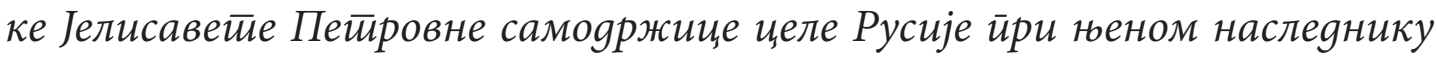

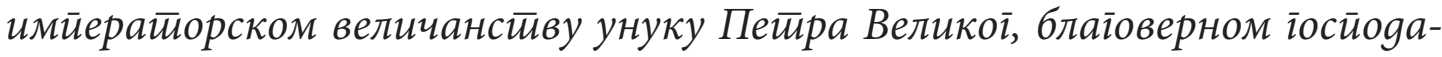
ру и великом књазу Петиру Теоgоровичу. По блаїослову најсветиијеі йрави-

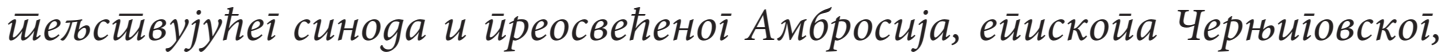

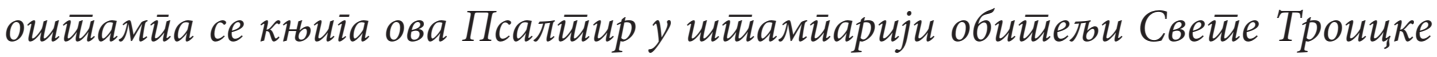
Илинско-Черниіовске ирри архимандритиу Ираклију, у летио оg сииваратьа

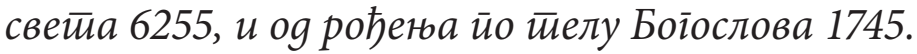

На првом листу налази се правоугаони печат на коме пише „Српски православни манастир Сопоћани” и број деловодника 37, што показује да књига припада братству Манастира Сопоћани. На унутрашњој страни налазе се белешке писане руком, тако да закључујемо да се Псалииир до пријема у манастир налазио код приватних лица.

Посебно су значајне и занимљиве напомене јер садрже податке о рукописним записима, посветама и потписима. Белешка на предњој страни руком писана изгледа као посвета: Њеіовоме йреосвешиивенсииву іосииоgину Мелетиију Рашко Призренском Б. Блаі̄оровном Госйоgару Тріовиу Пейру Вукaguнoвићy 1863. На следећем листу налази се четвртасти печат, новијег датума који није испуњен. На доњој маргини истог листа види се рукописна белешка која гласи: Ова кюиіа која се назива Пслатиир, мени Пеитру Кулаїићу, летиа їосйоgюеī 1832. На последњем листу стоји белешка из 1864. године, августа месеца коју преносимо дословце Павле, йойа Костиа Кулаїића, сину йссао у овај Псалйир. На истом листу у доњем десном углу, налази се округао печат који је нејасан, те није могуће да се утврди коме припада.

МОЛИТВОСЛОВ - Беч, 1771. - 56 стр; $19 \mathrm{~cm}$. Молитвеник је штампан на 56 страна и димензије је 19 x $30 \mathrm{~cm}$. Корице књиге су очуване са малим оштећењем на последњој коричној страни, папир је чврст, без оштећења, 
текст је потпун, слова крупна, читљива. Штампан је у царском граду Бечу 1771. године на рускословенском језику. Минијатуре су присутне кроз читав текст.

Иако се молитва може казивати на сваком местуㄱ, Молийвослов представља лични молитвеник, који се више користи у келији. На крају молитвеника налази се захвалница Богу, Богородици, Небеским чинима и свим светима. У овом молитвенику налазе се руком писане напомене које садрже податке о белешкама, посветама и потписима. На самом крају су записи, једва читљиви, уз које стоје године 1789. и 1792, за које закључујемо да су посвете. И на следећем листу стоји рукописна белешка која гласи: ДражацНеgељко Кайамација и Сара їосйђа. На крају књиге недостају два листа, очигледно исечена оштрим предметом.

ИРМОЛОГИЈА - Москва, децембар 1778. - 238 стр.; 15 сm. Књига има 238 страна и њен формат је 15 х 20 cm. Повез чине дрвене корице, пресвучене тамно браон кожом, без украса на коричном листу. Повез на хрпту је оштећен. На повезу се налазе две лепе копче и две траке које служе као међаши. Текст је читљив и има заставице на свакој страни. Ирмолоіија са псалмима представља збирку која садржи црквене химне и библијске песме које се читају (певају) током целе године, што представља поредак у богослужењу. Реч ирмологија настала је од грчког ирмос и представља почетну строфу православне црквене песме, према чијој мелодији се певају остале песме. По својој намени ирмоси могу да буду за осмогласнике (од 9 до 13 различитих ирмоса) и то за посебне празнике (Богородичине, Господње, ирмоси посвећени Крсту и др). Када се за сваки глас сакупе сви ирмоси, добијамо ирмологију. Да би се истакао значај празника који обележавамо, ирмоси се певају на почетку и на крају, и то само на литургији. У првом ирмологију даје се упутство за певање на служби.

Запис на илустрованој страни гласи:

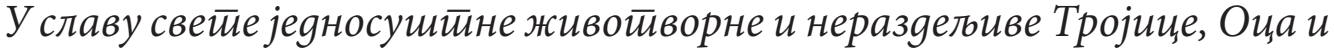
Сина и Свейоїа Духа. Зайовешћу Блаі̄очастииве самодрживе велике їосйоgарице наше имӣератиорке иеле Русије, Екайарине Алексејевне, ӣри наслеgнику юеном блаїоверном іосйоgару иаревићу и великом кнезу Павлу Пейровичу, и суйруїе юеїове блаїоверне іосйоgариие велике кнейиье Марије Теодоровне, и йри блаїоверном їосйоgару великом кнезу Алексанgру Павловичу, йо бла-

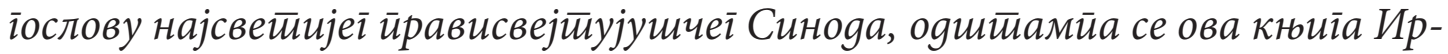

Ђорђе Трифуновић, Азбучник срйских среgюовековних књижевних йојмова (Београд: Нолит, 1990), 156. 


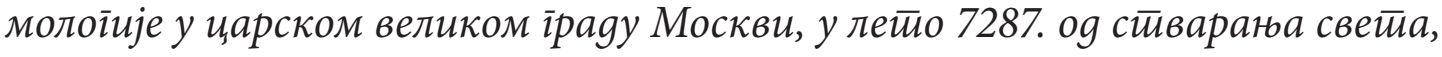
у gецембру 1778. og рођења йо иеелу Боіослова.

Ово издање Ирмолоіије штампано је 7287. по византијском рачунању, од стварања света, или 1778. На последњем листу се налази белешка исписана руком, која подсећа да је појац (певач) у храму од 1. јануара 1970. године и да је то био и касније. Име појца је непознато.

СЛУЖБЕ ПОСЕБНИМ СВЕТИМА - Кијево-печерска лавра, 1785. - 270 стр; $31 \mathrm{~cm}$. Службе посебним светима су исписане на 135 нумерисаних листова, што износи 270 страна. Формат књиге је 31 х $20 \mathrm{~cm}$.

Књига има кожни повез тамно браон боје, делимично оштећен на горњој и доњој страни хрпта. На предњем коричном листу налази се утиснути орнамент који симболизује Господа Бога са два анђела. На последњем коричном листу је орнамент који симболизује Мајку Божју која у наручју држи Господа Исуса Христа. Са леве и десне стране су светитељи Антоније и Теодисије, оснивачи Кијевско-печерске лавре. Папир је чврст, слова крупна, лако је читљив. Текст је написан на рускословенском језику, нема прекида и има минијатуре карактеристичне за тај период.

Уводни део записа гласи

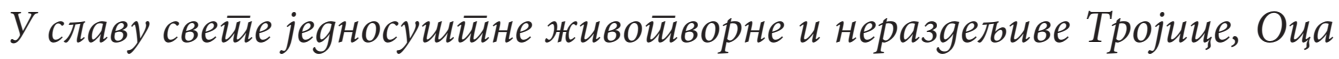
и Сина, и Светиоіа Духа: По зайовесиии Блаїочестивије самояржице велике іосйоgарице наше имйерайорке Екайарине Алексаняровне иеле Русије с юеним насле нницима блаїоверним іосйоgарем царевића и великої кнеза Павла Петировића и суйруїе юеїове блаїоверне їосӣоgарище велике кнеіичье Марије Теодоровне, и блаїоверне їосйоgе и великих кнежева іосйоgе Александра Павловића, и Консиианйина Павловића и блаіоверне іосйоgе и великих кнежева Алексанgра Павловића и Јелене Павловић, йо блаїослову најсветиијеі йра-

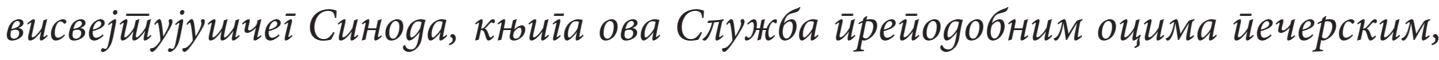
чије нетирулежне моштии йочивају у ближној и яально Пештери нетилено

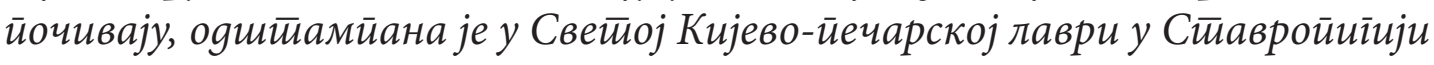

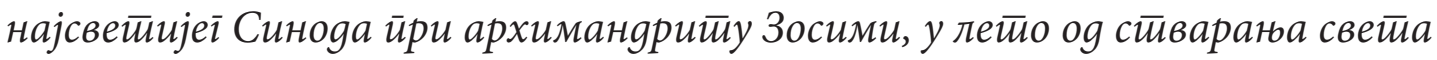
7293. и о рођень йо йелу Боіоослова 1785 индикйа 3, месеиа авїустиа.

Ово издање штампано је 7293. по византијском рачунању времена, од стварања света или августа 1785. године.

СЛУЖАБНИК - У Београду: Штампано у Штампарији Кнежевскосрпској, 1836. - 286 стр.; 23 cm. Служабник је штампан на 287 нумерисаних листова, а димензије књиге је 23 х $17 \mathrm{~cm}$. Повез је од дрвета, пресвучен кожом, делимично оштећен, са угравираним крстом на насловној стра- 
ни. На полеђини првог листа налази се округли печат који нисмо могли прочитати. На повезу су две металне копче и две траке које служе као међаши. Служабник је штампан на рускословенском језику. Има заставице које красе текст, а које се налазе на појединим листовима, и то на почетку или крају целине. Целокупан текст је очуван са незнатним оштећењима. Служабник је књига са црквеним службама вечерње, јутрења и литургије Светог Јована Златоустог и Светог Василија Великог ${ }^{8}$.

Уводни део записа гласи:

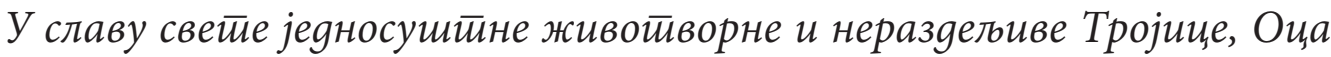
и Сина, и Светиой Духа: По зайовестии Блаїоверної Госйоgара Кнеза срйскої Милоча Тоgоровича Обреновича, ӣо блаїослову Просвећеної Архиейискойа Беоіраяскоі и иеле Србије Митироиолитиа Госйоgина Пеитра, оgитиамйа се ова књиіа Служебник у Беоіраяу, у Шииамйарији Кнежевско-срйској у летио og сииварана светиа 7346. og рођена йо иеелу Боїослова 1838. месеиа маја.

Ово је једина књига из нашег корпуса која је штампана у Србији. Књига је штампана по заповести благоверног господара кнеза Милоша Теодоровића Обреновића, у штампарији Кнежевско-српској у Београду, 1836. године.

МЕСЕЦОСЛОВ - Москва, 1810. - 300 стр.; 17 cm. Књига је штампана на 165 нумерисаних листова, и његове димензије је 17 x $10 \mathrm{~cm}$.

Повез је кожни, тамно браон боје, са малим оштећењима. На повезу се налазе две металне копче које су такође оштећене. Месецослов за целу iоguну штампан је у Москви на рускословенском језику. Папир је чврст, без оштећења. Текст је потпун, нема прекида, лако је читљив. На предњој страни налази се руком писана напомена из 1845. године која је делимично читљива. Месеиослов представља распоред са детаљима црквених богослужења за све дане у години, подељене по месецима. Овај Месецослов садржи црквени календар, објашњења и начин рачунања датума Васкрса, тропаре и кондаке за све дане богослужбене године.

Запис на илустрованој страни гласи:

У славу свете јеуносушитне живоивворне и нераздељиве Тројице, Оца и Сина и Светиоїа Духа зайовешћу најблаі̄очестивијеі самодршиа великої їосйоgара нашеі̄ имӣерайора Александра Павловића иеле Русије ... По блаїослову најсветиијеі йрависвејӣујушчеі Синоgа, оgщйамйа се ова књиїа

Трифуновић, Азбучник срйских среgюовековних кюижевних йојмова, 326.

9 Трифуновић, Азбучник срйских среgюовековних книжевних йојмова, 150. 
Месецослов за иелу іолину у иарском великом іраgу Москви, у летио 7360. og

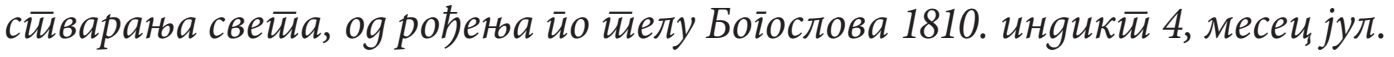

Ово издање Месецослова штампано је 7360. по византијском рачунању, од стварања света, или 1810. године.

ОПШТИ МИНЕЈ - Москва, 1862. - 332 стр.; 24 cm. Књига је исписана на 332 нумерисане стране и њен формат је 24 x $16 \mathrm{~cm}$. Повез чине залепљене платнене корице новијег датума, које не одговарају рукопису и времену настанка. Текст је писан на рускословенском, нема прекида, лако је читљив и потпуно очуван. Листови су чврсти, неоштећени, без илустрација и минијатура. Књига је штампана 1862. године у Синодалној типографији у Москви.

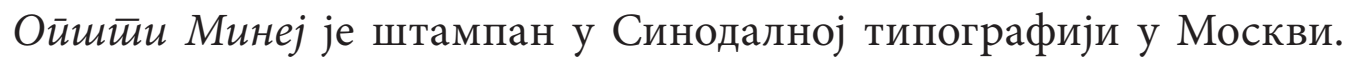

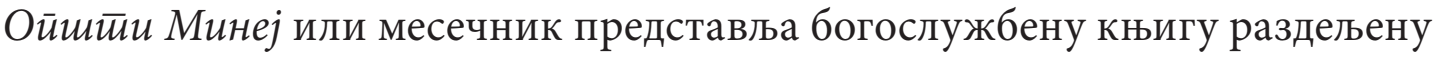
месецима у црквеној години. Службе једном или неколиким светитељима и празницима распоређени су по редоследу дана у месецу, то јест како који празник „пада"10.

Уводна страна је илустрована и садржи графику у облику записа који гласи: У славу светие јеgносушимне животиворне и нераздељиве Тројице, Оиза и Сина и Светиої Духа зайовешћу најблаїочестиивјеі самоgрииа великої їосйоgара нашеі имиератиора Александра Николајевића иеле Русије

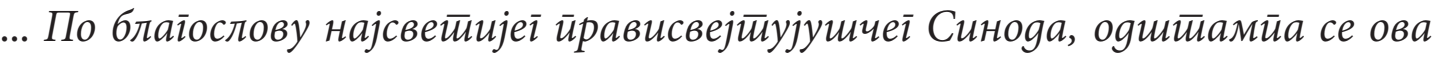
блаїонаgахнуйа кюиїа Оитити минеј у иарском великом іраgу Москви, у

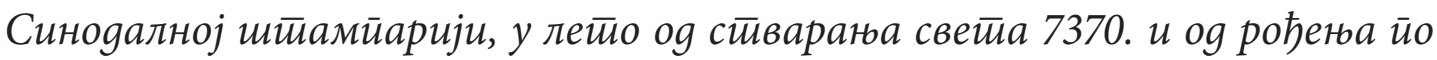

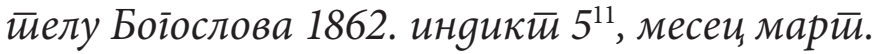

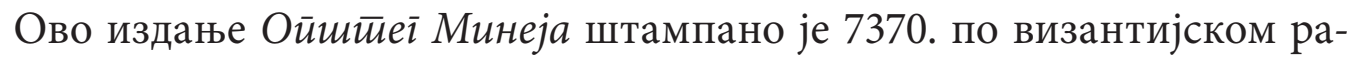
чунању, од стварања света, или 1862. године.

ПСАЛТИР - Москва, 1894. - 906 листова; 35 cm. Формат књиге је 35 x $25 \mathrm{~cm}$. Псалйир је штампан у Москви јануара месеца 1894. године на рускословенском језику.

Исписан на 906 нумерисаних листова. Књига има кожни повез и корични листови су делимично оштећени. Папир је чврст, слова крупна. Текст је на рускословенском језику, потпун и без оштећења, лако читљив. По својој форми ово је јединствена књига, уникатна, која је служила за

10 Трифуновић, Азбучник срйских среgюовековних книжевних ӣојмова, 151.

11 Индикти су важни због датума рачунања Васкрса. 
потребе цркве у критичним дешавањима. Он садржи неколико богослужбених књига: Псалимир, Величаније, Часослов, тропари и кондаци.

Уводна страна је илустрована и садржи графички цртеж на чијем врху се налази Господ Исус Христ који десном руком благосиља, а у левој руци држи отворено јеванђеље. Са леве стране је Свети Петар, митрополит московски, а са десне је Алексеј, митрополит московски. На почетку књиге налази се графички цртеж који представља лик пророка и цара Давида.

Посебно су значајне и занимљиве напомене јер садрже рукописне записе, посвете и потписе. Белешка на предњој страни је посвета дародавца који је рукойсс купио и поклонио братству. Година није позната: Ову књиіуy итлати 1000 gин. и ирриложи светиом Ман. Сойоћани Грешни Миљојко М Кривокућа Ковач из Равне Горе среза Моравичкої оg Иванице а за зgрављье себе и своје йородице и за милос и Блаїослов Свейоі Духа.

Важна напомена из 1897. године, руком писана, налази се на првих десет страна и сведочи да је рукопис приложио свештеник: Ову кюиіу итако звану Свеgоватетни Псалитир у знак блаїоgарностии на gосаgа учињеној услузи Манастииру В. Дечани Мра В. Дечани Јоаникије са својим брайсиивом шалье на gар иречасноме ирройојереју, Новойазарскоме іосиолину Рафаилу Кулаїићу, 2. фебруара 1897. іодине.

На 36. листу налази се рукописна белешка о монаху Досииејуу који је gошао у манастиир 1951. іолине. Замонашио се на Велики четввритак 1953. рукойоложен за Ђакона 14. јула 1953. и рукойоложен за јеромонаха 4. gецембра 1953. Према овом запису закључујемо када је Псалииир био активан.

3бог свеукупне ситуације, разних неприлика и ратних разарања, постојала је велика опасност да стара штампана књига нестане са ових простора. Да би их сачували, људи су их носили у манастирске библиотеке и поклањали. У интересу свих нас јесте да се стара штампана књига заштити и сачува и да се омогући њено истраживање. 


\section{Literatura:}

1. Gološ, Hivzo, Ahmed Bihorac i Mirsada Gološ. Kralj Stefan Uroš Prvi Nemanjić (1243-1276). Novi Pazar: Narodna biblioteka „Dositej Obradović”, 2018.

2. Kandić, Olivera i Desanka Milošević. Manastir Sopoćani. Beograd: Republički zavod za zaštitu spomenika kulture, 1994. (na ćirilici)

3. Mandić, Svetislav. Sopoćani. Beograd: Turistička štampa, 1965. (na ćirilici)

4. Mušović, Ejup. „Novopazarsko-prijepoljski kraj u turskoj administrativnoj podeli". U Simpozijum Seoski dani Sretena Vukosavljevića IV, urednik Petar Vlahović, 161-166. Prijepolje: Zajednica osnovnog obrazovanja, 1976. (na ćirilici)

5. Trifunović, Đorđe. Azbučnik srpskih srednjovekovnih književnih pojmova. Beograd: Nolit, 1990. (na ćirilici)

6. „Zakon o staroj i retkoj bibliotečkoj građi”. Službeni glasnik RS br. 52 (2011) (na ćirilici) 


\title{
Valerija Stefanović
}

Public Library „Dositej Obradović”, Novi Pazar

valerijanp@yahoo.com

\section{OLD PRINTED BOOKS IN THE NOVI PAZAR REGION}

\begin{abstract}
The research of the old printed books in Novi Pazar has a special and multiple significance and represents an important part of the local cultural heritage. The paper presents books kept in the library of the Sopoćani Monastery, printed in the period from 1745 to 1836 . The following religious books have been subjected to analysis: Psaltir from 1745, Molitvoslov from 1771, Irmologija from 1778, Službe posebnim svetima from 1785 , Mesecoslov za celu godinu from 1810, Služabnik from 1836, Opšti minej from 1862, and Psaltir from 1894. Judging by the content, these are liturgical books and belong to the collection of the old printed books. This paper aims to present them to the public and in this way provide new possibilities for researching the cultural heritage of the Novi Pazar region. The research of this material is very significant, and we hope that it will awaken interest among a wider public.
\end{abstract}

Keywords: old printed book, Sopoćani Monastery, Novi Pazar.

Примљено: 27. марта 2019.

Исправке: 30. априла 2019.

Прихвћено: 31. маја 2019. 